\title{
Reinvented Maidenhead in Commercialized Marriage: A Cultural Perspective on The Custom of the Country
}

\author{
Wan-Zhu OUYANG
}

\author{
College of Foreign Languages and Cultures, Sichuan University, Chengdu, Sichuan, China 610064 \\ wz_ouyang@stu.scu.edu.cn
}

Keywords: Edith Wharton; Consumerism; Cultural Studies; Marriage; The Custom of the Country

\begin{abstract}
Despite female employment in certain professions, most women before feminist movement, especially those from leisure class, practically resorted to marriage as a means of procuring financial support and domestic security, and thus being reduced to inferior status in domestic life in exchange for accepted position. Edith Wharton bucked the trend by portraying a female social climber in The Custom of the Country (1913), who utilizes marriage to her advantage, buying into aristocratic class with her erotic attraction. This reversal of female imagery, from a submissive figure at the mercy of the husband to the dominant, acquisitive one, is attributable to American consumer culture that took shape at the beginning of $20^{\text {th }}$ century. This study will investigate the cultural factor constituting the core of the novel and thus seeks to reveal the influence of American consumerism on the novelist and her framing of female characters. It defies the norms of stereotyping women in the writing of realistic novels by her male counterparts. The paper will examine how the consumerism exerts influence on formation of the protagonist's identity and conducts. Conducting cultural studies will shed a new light on inquiry into American society and culture in 1920 s by contextualizing the novel.
\end{abstract}

\section{Introduction}

In Consumerism and Girls Literature, Peter Stoneley deduces an exemplary formula from several American novels oriented towards young girls. It features development of a rustic, uncivilized girl, who is led to maturity after receiving education in metropolis and gratified with wealthy husband and higher social position. Her wilderness is tamed and eradicated through acculturation to suit her future role in marriage life. Such heroine is emblematic of the transformation of an uncouth America, being institutionalized with capitalist ideology, into a highly developed country in accordance with the norm of modern civilization. Likewise, the girl-heroine has to learn how to purchase and consume to become civilized. It is because the act of consumption, which is maneuvered by market demand and production, will guide and discipline disoriented human desires, and cultivate individual into reasonable, practical consumers, according to Baudrillard. Unmarried women who are institutionalized with the governing laws of commercial society will then properly construct their post-marital identity and orient their relationship with family members accordingly. So the acquisition of consuming behavior that is central to economic stability will also initiate the young heroine into adulthood. The heroine embodies the extension of social demand and desire as well as an accepted pattern to be modeled after. In consequence, female readers, especially the unmarried ones, are introduced to these readings for their implicitly didactic functions which can assuredly lead women into the domestic role the society expect them to fill.

By this analysis, Peter Stoneley perceives implicit causality between genesis of consumer culture and commercialization of women in American literature during 19th century and 20th century and infers that girls' literature, either "for" or "about" girls, is produced with clearly didactic purpose. This conclusion, however, fails to anticipate the potential outcome that overindulgent consumption may provoke female customers' insatiable appetite for pricey items, not the other way around. Their consumption practices will also frame the buyers' world view, and shape their identity and relationship as well. Zygmunt Bauman, a Polish sociologist, argues in his Consuming Life that consumption-oriented mindset "manipulates the probability of individual choices and conducts", 
not only in purchasing something substantial, but in pursuing something intangible but socially valuable. For this reason, marriage with collateral yields can be bought, or invested, by profit-driven marriageable women who seek to purchase eligible husband. This new concept anticipates the rise of flappers in 1920s' American popular fictions which featured utilitarian marriage. The wife appears to be more of a pragmatic businessman than a qualified commodity in the marriage market portrayed in Stoneley's surmise. This paper purports to argue that the heroine of The Custom of the Country is not an anti-patriarchal figure but a product of consumer culture, which removes the gender boundary and construct new identity for women in a world of exchange. I will proceed to examine how the consumerism take effect, in The Custom of the Country, in constructing counter-current woman who self-consciously pursues marriage and divorce in her interest.

\section{"From Scratch to Richness" and "Buying into Womanhood"}

A female novelist of controversial reputation, Edith Wharton goes against the grain and writes girls' stories that turn out to vary greatly. She dramatizes fateful collapse of a commodified woman in House of Mirth and banishment of a woman from elite class in pursuit of freedom in Age of Innocence. She also provides an anti-hero being criticized as ruthless, intrusive, destructive and masculine in The Custom of The Country, which triggers much more disparaging responses from critics. The scandalous divorce and extramarital affiliation of Undine Spragg, in correspondence with the author's own love affairs and divorce, intensify critical animosity towards the fictional figure and the author per se. These female characters unexceptionally share consumerist traits, alluding to the atmosphere of consumerism in which the author was born and brought up.

In light of her mercantilism and pragmatism, Undine Spragg, the heroine, transgresses the social norms that prescribe defining attributes for female figures in traditional feminine literature. Margaret B. McDowell ascribes the deviant behaviors of women characters and resultant destiny befalling them respectively in Wharton's fictions to her budding feminism. McDowell generalizes that Wharton's depiction of women characters registers the suppression and exploitation of inferior sex by patriarchal society; in spite of female status at the mercy of social conventions, derision from the conservatives can hardly erode their awakening self-awareness and insubordinate pose. But Wharton invalidates McDowell's conclusion by presenting Undine Spragg as a sophisticated businessman who utilizes her sexuality (i.e. maidenhead) to achieve ascendancy whereas female sexuality as subject matter in other literature is used to allude to male dominance.

Following its predecessor The House of Mirth, The Custom of the Country is characteristic of its literary lineage as portraying decadent leisure class in consumer society and tracing the destabilizing factors that cause such changes. Yet the author is more calculating this time by change of perspective from puppet-like upper-class women to a female aspirant who manipulates her several marriages in exchange for higher echelon in class society. Fresh from her concealed elopement and divorce with a rascal, the protagonist of The Custom makes her debut in New York high society as a young protege of an aristocratic lady, full of virginity and innocence. The fact turns out to be that the socially naive girl "is conceived as a bankrupt entrepreneur" and a veteran of flirtation in pursuit of social promotion through marital transaction owing to her gender inferiority. At intervals, her maidenhead is symbolically restored to render her a virgin for the second time, awaiting match-making in the marriage market. Wharton drew inspiration from an eponymous stage play written by John Fletcher when she entitled her fiction. The title, The custom of the country, is taken from the an English play, which refers to an outdated convention that a feudal lord in medieval Europe can exercise his droit du seigneur, which means laying a claim to the virginity of all young girls within his domain. Maidenhead in this play is both symbolic of sexual objects and connotative of female subjection. Ironically, in Wharton's fiction, maidenhead transforms into armory to testify its value in marriage pit and to expose the effeminate aspects of aristocratic class. The adventurous Undine reminds readers of another female speculator in $19^{\text {th }}$ century Britain. Becky Sharp, who is upwardly mobile through marriage and flirtation in a mercenary world that features achieving prosperity through commerce and trading, has striking resemblance to Undine Spragg in terms of their social background, means of procuring wealth and trajectory of life. Both 
of them show strong proclivity in constituting threat to male-dominated society and little interest in traditional female role in domestic sphere; both of them fully exploit sexual attraction of female body buying into high society and end up leading a luxury life. In a society where females are deprived of choices and restrained in social confinement awaiting for prospect customers in marriage market, Undine and Becky overthrow the seemingly unchanging constraints by managing to monetize their body instead of being commodified. The heroine resembles money in not only creating extra value out of herself but exciting urges to buy something and "only what others value, even shaping herself to the standards of other." Stripped of her charming elegance, Undine Spragg is as much calculating and merciless as a business tycoon in the Gilded Age. The strategy used by the heroine connotes the author's familiarity with social and cultural milieu of capitalist society in which consumerism held sway, despite some previous suppositions that feminist movement may inform the writing of The Custom of the Country. Undine Spragg is more of an embodiment of American culture that features pragmatism and consumerism than a rebellious gesture towards patriarchal society.

The story about how the Spraggs aggrandize their fortune is based on the factual life experience of Joseph Wharton, a distant relative of the author's husband, who schemed to secure huge profits by running a project that supplies pure water to Philadelphia. Despite the abortion of this project, Edith Wharton fictionalizes his miscarried plan and displaces it unto the business adventure of Abner Spragg according to her first-hand knowledge of the story. The fictional water-supply project runs counter to its counterpart in reality; it brings to Abner Spragg giant wealth and firm foothold in business circle. Yet the motive behind Mr. Spragg's initiative might not be so noble and selfless as in Mrs. Spragg's recounting of this enterprise to Ralph Marvell. Two siblings of Undine's died a premature death because of the epidemic typhoid caused by destitution of clear water in Apex. Mr. Spragg vows to supply pure water to children of the entire area after witnessing the decease of his kids, not predicting that the enterprise of public interests would initiate the self-made man out of financial straits and into elite class in Capitalist world. Such high-minded objective exonerates him from ulterior motive and illegal dealings but Wharton's emphasis on ignorance of Mrs. Spragg and Ralph Marvel has some connotative meanings. When Undine slips into her adulthood, the Spraggs hastily pull out of local business and move to New York city, too hastily to exempt Abner Spragg from suspicion of illegal involvement in Pure Water Move of Apex. Moffatt's sudden visit to Mr. Spragg's office in Wall Street provides further testimony to confirm our former speculation: he threatens to disclose the elopement and marriage between Undine and him with the purpose of extorting from Mr. Spragg blackmail material on Rolliver (Rolliver is a representative who was suspected of illegitimate conduct in Pure Water Move in collusion with Spragg ). Spragg concedes to the threat and hands over the material, not only for fear of discovery of his daughter's scandal but also for fear of leakage of his entanglement with Rolliver.

Witnessing how her father scrambled up the social ladder, Undine Spragg is instilled with her father's business wit and underhanded mind. And moreover she is endowed with proactive and autonomous spirit to select out the optimal suitor while conquering her disadvantages, instead of being chosen and married off. She is more of a businessman than her father is. Her parents are displaced and uprooted from Apex to New York due to her strong urge to broaden her scope for marring well, as Donald Trump claims in his brochure for entrepreneurs, "Great men always gravitate to the metropolis". In his The Art of the Deal, Trump sets the pattern of trajectory for roughneck aspirants: the billionaire and his artful wife itinerate around the metropolis a la mode on the prowl for valuable items as does the circulating medium in the world of exchange. His precise description corresponds to Undine's course of life constantly on the move and constantly spiraling upward; Undine's movement also corresponds to the flow of capital, from individual to individual, from household to household and from nation to nation. Elizabeth Ammons notes that women like Undine Spragg are shut out from business battlefield of Wall Street owing to their gender but given their own stock exchange. In other words, these pugnacious businesswomen are as versatile in marriage market as their male counterparts in stock market.

In the first few chapters, Undine plays a virgin in disguise, chaperoned by Mrs. Heeny while 
skillfully concealing her elopement and first divorce with Elmer Moffatt in Apex when she is introduced into high society. She successfully hooks up the highbred Ralph Marvell with false virginity and removes the obstacle of her low birth. Yet the halo of high social status cannot offset impoverished state of Ralph as Undine finds that their financial strait can rarely afford her luxury life. She quickly targets Peter Van Degen as her next prey in prospect and develops an immoral relationship with him.

Extramarital affair is extensively narrated in Wharton's fictions, according to Margret McDowell, as an alternative for women imprisoned in loveless wedlock, to vent for their repressed emotion. The author shows great attention to female misconduct not out of religious or moral consideration but for the sake of frame-up crime imputed to women. The author's total disregard for social morals testifies to her feminist tendency. But Undine Spragg's active foray into extramarital relationship with her cousin-by-marriage, Peter Van Degen and her scheme of remarrying this nouveau-riche entirely negates McDowell's surmise. Like her financier father who attempts to secure a firm footing and bountiful reward in Wall Street, Undine takes initiative in adultery driven by ulterior motive of marrying for great fortune, but in vain. The father and the daughter are alike being frustrated in their expectation but Undine proves to be more elastic and prudent than the elder Spragg. Her project of restoring her former status before divorce is going to be executed in her forthcoming marriage to a French aristocrat. To achieve her goal, she has to conquer the religious barrier that may forestall the marriage because the Catholic Church prohibits divorce and remarriage. Undine manages to extort enough money from her ex-husband to bribe the Pope by threatening to snatch away their son from Ralph, of whom Undine has taken custody. Upon hearing the ignominious past of Undine from Moffatt and foreseeing imminent departure of his son, Ralph Marvel commits suicide and his timely death expedites Undine's third marriage. Undine reclaims her reputation and seals the deal at the expense of her former husband. That the overdue payment of Ralph's investment in Moffatt's business coincidentally renders him unable to meet the deadline of blackmail is indicative of Undine's murder of Ralph in cahoots with Elmer Moffatt. She reinvents her maidenhead to buy into womanhood within domestic circle but ironically ends up devastating conventions and deep-seated values; the morally void woman incessantly purchases husbands to gratify her desires and later has them tossed away when they were exploited. Even though she reunites with Elmer Moffatt at the end of the novel, and her former lover and accomplice whose rogue temperament best suits hers, she still speculates on her next marriage with an ambassador.

These facts verify her as a mere artifact of highly consumerist phenomena and embodiment of capital in constant circulation. She has to market herself, sticking price tag on her sexuality and making it legitimately eligible in transaction. Beverly R. Voloshin likens Undine Spragg to the "capitalist hero", who "is her own capital and the aura of that capital, her own broker, her own market. Ticien Sassoubre regards the protagonist as a frustrated entrepreneur forced by her gender to pursue her business in domestic sphere." Although capitalism and industrialization in 19th century America consolidated the role assigned to woman and man separately, their domains overlapped to some degree. Women who are inculcated with consumption habit of by growing market economy, are accustomed to "buying" to satisfy their rapacious appetite; the act of buying is a connotative gesture of conquest. Meanwhile the word "buying" extends beyond its literal meaning which renders the purchasable objects inclusive of some items ineligible for trader. In this sense, unmarried woman can afford a satisfying husband with her properties as man carries out transaction with others. Both man and woman are commodified and simultaneously commodify others. Therefore readers will not surprisingly find that the excursion of Undine Spragg transgresses the conventional domain assigned to housewives and thus blurs the demarcation between men and women. That she has no apprehension of conscious self-commodification may be testimony against her business wit, however, the fact that she acts on her instinct and impulse to wade through her marriage deals fully testifies to identity and personal attributes constituted by consumerism and market economy.

Given that the rise of Undine Spragg parallels that of her male counterpart Elmer Moffatt, male legend of "from scratch to richness" and female criteria of "buying into womanhood" can be 
applicable to both cases. It clarifies that the identity of Undine Spragg and Elmer Moffatt is interchangeable against their shared cultural background; the author's characterization breaks free from the limits of stereotyped imagery as represented in former novels.

\section{Commodified Men and Personified Commodities}

In her four sequential marriages, Undine Spragg demonstrates great cognitive disparity with her husbands in terms of personal identity and personal possession. The novel resembles an arena where contradictory views compete for domination. For Ralph Marvel and Raymond de Chelles, an item is being endowed with inalienable and irreplaceable value once it comes into their possession and their linkage to their property gives them a sense of stability, which is disrupted and superseded by the uncertainty of capitalist society. Each item is obtained without engaging into circulation for the second time. The physical property of non-fungible objects are somewhat invested with individuality and for years transformed into a stagnant complex of lineage, history and culture. This notion is quite incomprehensible to the aggressive outsiders (Undine Spragg, Van Degen and Elmer Moffatt, etc.), most of whom are new creatures of capitalist market deeming everything as salable commodity. For example, Raymond was staggered on hearing Undine's notion of selling Saint Desert, the chateau that belongs to the Chelles, in order to afford her luxury lifestyle. The proposal seemed to him "as monstrously, almost fiendishly significant" since the chateau embodies continuity of ancestry which necessitates aggrandizing its value through efforts of several generations. Likewise, when Undine had the tapestries of the Chelles appraised, Raymond was infuriated by his wife's vulgar indulgence for money, "Ah, that's your answer - that's all you feel when you lay hands on things that are sacred to us!" The tapestries given by Louis XIV to his family, are too noble to be debased to equivalent of money as they are infused with regal sublimity and historical profundity, let alone their aesthetic significance. For years people like Chelles and Dagonets will develop a kind of indissoluble bond with growing property, which is analogous to interpersonal relationship as the property is involved in the shaping of the possessors' identity and worldview. Ralph, for example, realized that the Dagonet attitude, the Dagonet view of life, is inscribed in "the very lines of the furniture in the old Dagonet house". Another telling scene is that when ascending his grandfather's doorstep, Ralph "looked up at the symmetrical old red house-front, with its frugal marble ornament, as he might have looked into a familiar human face". Unfortunately, the stability of domestic sphere in the embrace of properties that preclude uncertainty from outside world in flux, finally succumbs to the instability of market, where the parvenu gain huge profit to buy the social position and possession of old nobility. When deprived of their property and stable relationship, the conservative class crumbles into cinders.

Contrary to the immovable old nobility, the new creatures of market economy have no sense of belonging or affiliation to physical objects and interpersonal relationship. This sort of people is best exemplified by Undine Spragg. Humans can be bestowed with values equal to commodities in the free market only if they are instrumental to achieving other goals, namely, goods and people are exchangeable. That's the root cause of "her willingness to exchange sex for status and her child for cash" and her presumption of resetting the Dagonet family jewelry; she sees the circulation value rather than intrinsic value of physical possession, not to mention aesthetic and emotional value attached to it. She commodifies her physical beauty, her only son (she held her son hostage for large ransom from Ralph and indirectly caused Ralph's death) and her three husbands without exception in exchange for more desirable life while capitalizing on her social relations too for personal purpose - she introduces her French friends to Indiana Frusk to gain access to her future paramour Van Degen and rekindles Moffatt's interest in her by channeling him into the fine collections of French aristocracy. Free from any constraints that accompany interpersonal bond and interrelation between person and possession, Undine Spragg is versatile in all sorts of contractual exchange with mutable identity.

The other two outsiders, Van Degen and Moffatt, are slightly different from the protagonist in light of their notions about differentiation between individual and lifeless object. Undine is too void of finer sense to know the intrinsic values of an object whereas Moffatt is clear about the historical 
and aesthetic significance of it. Instead of establishing an everlasting, inextricable relationship, Moffatt collects these family heirlooms in order to charge a high price when he translates their added value into market term. In contrast, Van Degen is more of a customer than a astute merchant. Though marrying a girl from old family and escorting his wife to appreciate fine arts, he is materialistic to the core, holding deep conviction that everything can be converted into its cash equivalent. His association with high society only serves his purpose of invading the exclusive social circle and conquering the conservatives with his money. Even Undine is overwhelmed by his obsession with money. Along these lines, the concept that sacred marriage fosters eternal stability and family unit stays invariable is completely disposed of when marriage and the individual agents involved are seemed as material commodity. It means that marriage and family can be consumed and resold, and their existence becomes evanescent and dissoluble as a consequence. As Lori Merish states in Sentimental Materialism, the act of consumption gains new dimension when transported to the American society where the capitalism took root. She argues, eighteenth-century consumerism engenders cultural construct of female identity and material object, which separates private life from public sphere and meditate between the two contradictory domains. So the engagement ring presented by Ralph Marvell carries multiple symbolic meanings: the piece of jewelry is refined works of art and its civilizing force aims at those who marry into aristocracy because the aristocracy never buy engagement rings; on the other hand, the ring turns out to be a exchangeable purchase in the eyes of Undine and her mother. Into twentieth century, Merish continues, the reinvented capitalist economic and commodity composition help the suppressed market-oriented private life reappears by revealing that the private, domestic space above materialistic society is actually activated by consumer psychology "in which individuals "express themselves' through consumption and identify with personal possessions". It substantiates the association between influence of consumerism on the protagonist and breach of her four marriages.

\section{Conclusion}

The Custom of the Country is anti-epic about how the anti-heroine trades on her marriage and leads a schizophrenic life either as a businessman or as a commodity. Moreover, the fiction is a satire on Americans' mental void and blind quest for vanity. The protagonist's mutability and nomadic way of life are typical of brokers who swarm into profitable trade. Her insatiable desires for better things direct her to persistent pursuit even though she lacks specific motivation and objectives. Vicarious and amateurish as she might be due to her subaltern place in a rigidly stratified society, she was equipped with blunt acquisitiveness and quick mind enough to wade through her business deals thanks to her heredity and environment. Not only in her marriage, her pragmatism and business skills brimmed over in minor dealings: offering Ralph practical suggestions, hocking Van Degen's pearls to speculate on her next marriage and robbing Ralph of Paul to amass her bribery. Her lacks of appreciative faculty for fine arts and intrinsic value throughout the book satirically demonstrates American ignorance and pragmatism in dealing with items shielded from market; her predilection for dazzling, flamboyant ideas of Popple, a pseudo-artist who produced full-length portrait of Undine, indicates the author's slight for vulgar, frivolous aesthetics that American popular culture adores. Undine's constant associating artworks with prices also reflects that the operative mechanism behind American culture industry is to stimulate customers' impulses to buy. In spite of her blindness and vainglory, Undine Spragg is in the vein of modern American culture and her cultural aspect diminishes her gender identity and social identity.

The author takes a commercialized woman and people around her, typical of new American generation produced in the heyday of capitalism, as subject matter, to study how American ideology takes effect under the operation of commercialism and consumerism and what begets schism between competing views. As Elizabeth Ammons notes, The Custom of the Country is "one of America's great business novels," and Robert Caserio deems the character of Elmer Moffatt serves as the archetypal figure of financial and political figures in later American realist novels. 


\section{References}

[1] Ammons, Elizabeth. "The Business of Marriage in Edith Wharton's The Custom of the Country." Criticism 16.4 (1974): 326-338.

[2] Bauman, Zygmunt. Consuming life. John Wiley \& Sons, 2013.

[3] Collins, Alexandra. "The Noyade of Marriage in Edith Wharton's The Custom of the Country." English Studies in Canada 9.2 (1983): 197-212.

[4] Elizabeth Ammons, Edith Wharton's Argument with America (Athens: University of Georgia, 1980), 109

[5] Bloom, Harold, ed. Edith Wharton. Chelsea House, 1986.

[6] Jordan, Elizabeth A. From world war to consumer culture: an investigation into Edith Wharton and the 1920s. Diss. Durham University, 2003.

[7] Lori Merish. Sentimental materialism: gender, commodity culture, and nineteenth-century American literature. Duke University Press, 2000.

[8] McDowell, Margaret B. "Viewing the Custom of her Country: Edith Wharton's Feminism." Contemporary Literature 15 (1974): 521-538.

[9] Stoneley, Peter. Consumerism and American Girls' Literature, 1860-1940. Vol. 134. Cambridge University Press, 2003.

[10] Trump, Donald J., and Tony Schwartz. Trump: The art of the deal. Ballantine Books, 2009.

[11] Voloshin, Beverly R. "Exchange in Wharton's" The Custom of the Country"." Pacific Coast Philology (1987): 98-104.

[12] Wharton, Anne H. Genealogy of the Wharton Family of Philadelphia, 1664 to 1880. Philadelphia: n.p., 1880.

[13] Wharton, Edith. The custom of the country. OUP Oxford, 2000. 